\title{
Development of 3-Dementional Conceptual Model of Teaching Practicum in Korea
}

\author{
Hyeon-Ju, Choi, Full-time Researcher, The Center for Global Teacher Education, Gongju National University \\ of Education,woongjin-ro, Gongju-si, Chungnam,32553 Korea, choi2005@hanmail. Net \\ *Il-Soo, Park, Professor, Gongju National University of Education, woongjin-ro, Gongju-si, Chungnam, 32553 \\ Korea,edupark@gjue.ac.kr \\ Yang-Hwan Sol, Professor, Gongju National University of Education, woongjin-ro, Gongju-si, Chungnam, \\ 32553 Korea, yhsoll@naver.com \\ *Corresponding Author
}

\begin{abstract}
The aim of this study is to develop a conceptual model of teaching practicum for systematic understanding of the phenomenon of the teaching practicum and the efficiency of $i$ ts operation. In this study, the core elements of a teaching practicum were derived through 1 iterature analysis. First, the 'phase' of teaching practicum, second, the 'type' of teaching practi cum, and third, the 'support system' for teaching practicum. The researchers developed a 3D teaching practicum concept model using these three elements as the three axes of the mode l. The conceptual model-of-teaching practicum developed in this way was validated by an opi nion survey undertaken by two groups of experts. The expert opinion survey was conducted with a group of 20 university professors and 13 professional teachers. As a result of analyzi ng the survey data, the CVR value was analyzed to be 0.42 or higher in the 1st expert gro up (professor group) and the CVR value above 0.62 in the 2 nd expert group (13 professiona l teachers). As a result, the conceptual model of teaching practicum developed in this study was verified and the dimensions, sub-elements, and definitions of each were valid. The conce ptual model-of-teaching practicum created through a theoretical approach can be used as basic data for systematic understanding and efficient operation of the phenomenon of the teaching practicum.
\end{abstract}

Keywords: a conceptual-model-of-teaching practicum, three-dimensional elements, phase, type, s upport system

$\begin{array}{lll}\text { Received: 09.12.2020 } & \text { Accepted: } 17.01 .2021 & \text { Published: 07.02.2021 }\end{array}$

\section{INTRODUCTION}

The teaching practicum in Korea is operated differently by each teacher training institution, and the content and quality of the training are influenced by the teaching ability of the schools and mentor teachers[5,12]. In particular, in the case of secondary teaching practicum, there is a serious difference in the type and quality of teaching practicum experienced by student teachers compared to that of the primary teaching practicum. Consequently, it is a common criticism that secondary teacher training institutions neglect teaching practicum[7]. To this date, many studies have been carried out to solve these problems. However, the studies lack systematic discussions to enable a practical improvement in the teaching practicum by dealing with overlapping discussions centered on the phenomena and examples of the teaching practicum.

Also, Korea's research on the teaching practicum model has been done in very limited areas. For example, they have been carried out primarily in infant education[10,6,3] or in special education areas for children or persons with disabilities[1,10,11]. As such, Korean studies have tried to develop a model of teaching practicum operation in certain areas, such as infants and special education, but little has been done to develop a model for primary and secondary teachers that is most commonly needed. Many years ago, a study took place, which suggested the development of a cooperative system model between universities and cooperative schools to improve the teaching practicum[2]. Afterwards, a study was conducted to develop hands-on training programs to encourage prospective teachers' reflective thinking skills[8]. However, these studies are limited in their use as a general model of teaching practicum in primary and secondary schools, as they were aimed at developing a model of teaching practicum on a specific subject. So far, few studies have attempted to develop a basic conceptual model that is generally 
applicable to training elementary and secondary school teachers. Fortunately, some universities have recently tended to develop their own operating manuals or models for training operations at each university.

Therefore, this study has attempted to develop the most general teaching practicum operation model that can solve the problems of the primary and secondary teaching practicum. To this end, the researchers analyzed the relevant literature on teaching practicum, operational data, etc. to derive the conceptual elements of teaching practicum and visually reveal them to systematically understand the elements of teaching practicum. As a result, the researchers developed a conceptual model for the teaching practicum. This conceptual model-of-teaching practicum will contribute to a better understanding of teaching practicum by systematically revealing the ideological elements included in the concept of teaching practicum. It is also expected to enable a more structured discussion on how to improve actual training practice operations. Therefore, the research questions in this study are as follows.

First, what are the key elements of teaching practicum?

Second, how can the conceptual model of teaching practicum be created and devised?

Third, what are the implications of a conceptual model of the teaching practicum for theory and practice?

\section{Methods}

First of all, this study explored a theoretical approach. The theoretical approach was to analyze literature and research related to the teaching practicum, and derive key elements of teaching practice based on the analysis results. After that, a conceptual model was devised by selecting the core elements of the derived teaching practice as three axes. Finally, the validity of the model was verified through an expert opinion survey on the proposed concept model. The study procedure is shown in Figure 1.

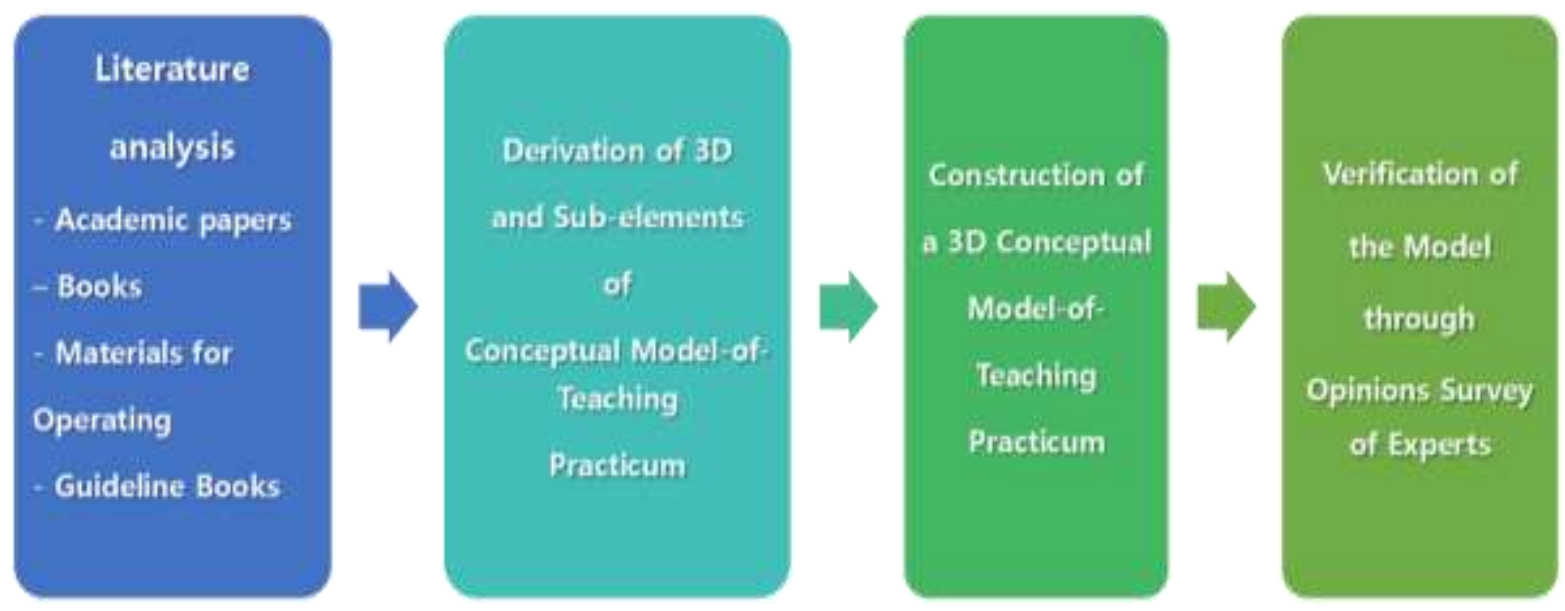

\section{Figure 1. Research Procedure}

\subsection{Research Participants}

Participants in this study were two groups of experts. The researchers conducted an opinion survey on the validity of the model using these two groups. The first group of experts consisted of university professors with research and guidance experience in teaching practicum. The total number of these was 20, including 10 professors at elementary school teacher training institutions and 10 professors at secondary school teacher training institutions in five regions (Seoul / Gyeonggi, Gangwon, Chungcheong, Honam, Gyeongsang / Jeju). These are all experts in the field of the teaching practicum, who have previously conducted research on the teaching practicum at universities and have experience in practical training or are interested in the teaching practicum. The second group consisted of professional teachers who directly guided the teaching practicum in the school field. These were 13 teachers who were all teaching practicum tutors while working at a school affiliated with an elementary school teacher training institution. Researchers e-mailed these two expert groups to ask about the validity of the conceptual model and compiled their responses.

\subsection{Data Collection}

Between February and June 2019, the researchers collected literature on teaching practicum. The 
collected materials included national guidelines, books related to teaching practicum, academic papers, operating guidelines and plans for each school. The collection method was conducted by searching the internet and the website of each teacher training institution, and requesting teacher training data from each teacher training institution via official letter and telephone. Researchers analyzed the collected data from June to August 2019 and reflected it in model development. In addition, in order to verify the validity of the proposed model, the first expert group opinion survey was conducted from February to March 2020, and the second expert group opinion survey was conducted from July to August 2020. Questionnaires and responses for expert opinion surveys were sent and collected by email. Each question was constructed to be answered on a 5-point Likert scale to provide a reasonable level of answer.

\subsection{Data Analysis}

As data analysis, literature analysis and questionnaire data analysis were performed to verify the validity of the model. First, the literature analysis was conducted in a way that repeatedly read the collected data, analyzed and categorized them by common themes, and derived the common elements of the teaching practicum. Next, based on the common elements analyzed earlier, a conceptual model-ofteaching practicum was devised and the survey data on its validity were analyzed. To this end, the researchers analyzed the collected data using Excel and SPSS 18.0. The mean, standard deviation, degree of agreement, and content validity (CVR) calculated as a result of the analysis verified the validity of each dimension of the conceptual model-of-teaching practicum and its sub-elements. According to Lawshe's (1975) suggestion, in general, if you have 10 experts, you can consider a CVR value of 0.62 or higher as valid. In addition, it can be said that the validity was secured only when the CVR value was 0.42 or higher for 20 experts and the CVR value 0.37 or higher for 25 .

\section{Result and Discussions}

\subsection{Derivation of 3-Dimension and sub-elements of a conceptual- model-of- teaching practicum}

\subsubsection{1-Dimension of conceptual Model: Phase}

The first element of teaching practicum derived from this study is the 'phase' of the teaching practicum. This is an element selected as the first dimension of the model-of-teaching practicum and means an appropriate process or procedure for the teaching practicum. The teaching practicum in Korea consists of three phase: pre-orientation before teaching practicum, teaching in action practicum, and evaluation after teaching practicum, which is an essential phase for training and practice. This is shown in Figure 2.

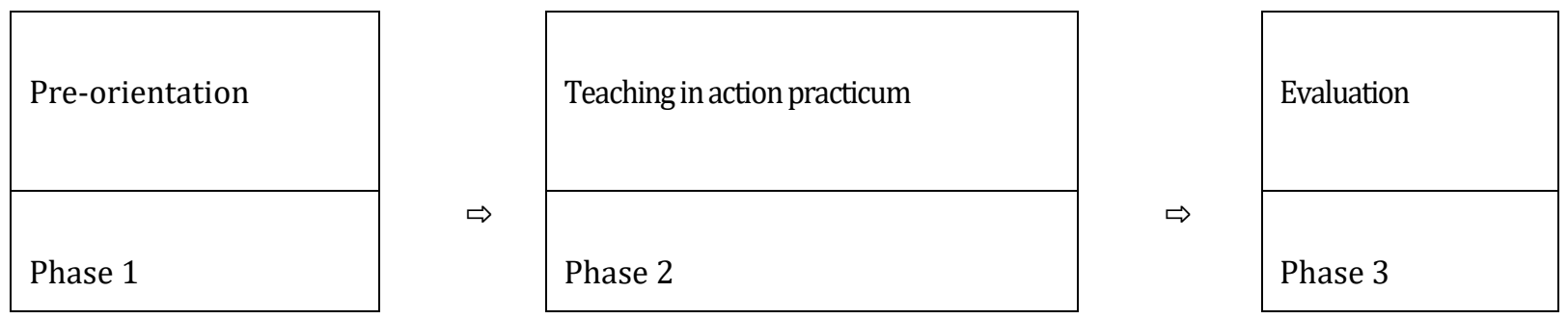

Figure2. The Phases of the Korean Teaching practicum

\subsubsection{2-Dimension of conceptual Model: Type}

Next, the second element of the practicum is the type of practicum. After completing the preorientation, student teachers enter the school site and begin training in earnest. However, the contents of the teaching practicum that can be performed in the early stages of the teaching practicum are not the same as those in the middle or later stages. Student teachers experience increasingly intense educational activities from the start of the teaching practicum to the middle and later stages. In other words, at the beginning of the teaching practicum, observation and participation activities usually take place, but in the middle stage, student teachers experience classes with observation activities. In the later stages of the practicum, student teachers can continue their early and mid-term activities to gain a comprehensive experience of practical practicum activities. In Korea, the content elements of these exercises are classified 
into 'classroom observation', 'teaching practicum', and 'practical practicum'. Therefore, the second dimension of the model-of-teaching practicum was set to "Type", which categorizes the content of the teaching practicum.

\subsubsection{3- Dimension of conceptual Model: Support System}

Finally, the human and material elements that plan, operate, and support the teaching practicum are the Provincial Office of Education and its administrators, universities, professors, schools, and teachers. These three factors were analyzed as being very important for a successful teaching practicum. In particular, the linkage and cooperation between these three factors is very important in that it can act as a facilitator to increase the efficiency of the teaching practicum. Therefore, the researchers classified human and material elements as 'support systems' and selected them as the third dimension of the model-ofteaching practicum.

\subsection{Construction of a 3D conceptual model- of- teaching practicum}

In this study, we have constructed the conceptual-model-of- teaching practicum. The conceptualmodel-of-teaching practicum was organized in three dimensions based on the research literature on the teaching practicum performed so far. The three dimensions of the conceptual-model-of-teaching practicum developed by researchers are the first, 'phase', the second, 'type', and the third, 'support system'. This is in figure 3.

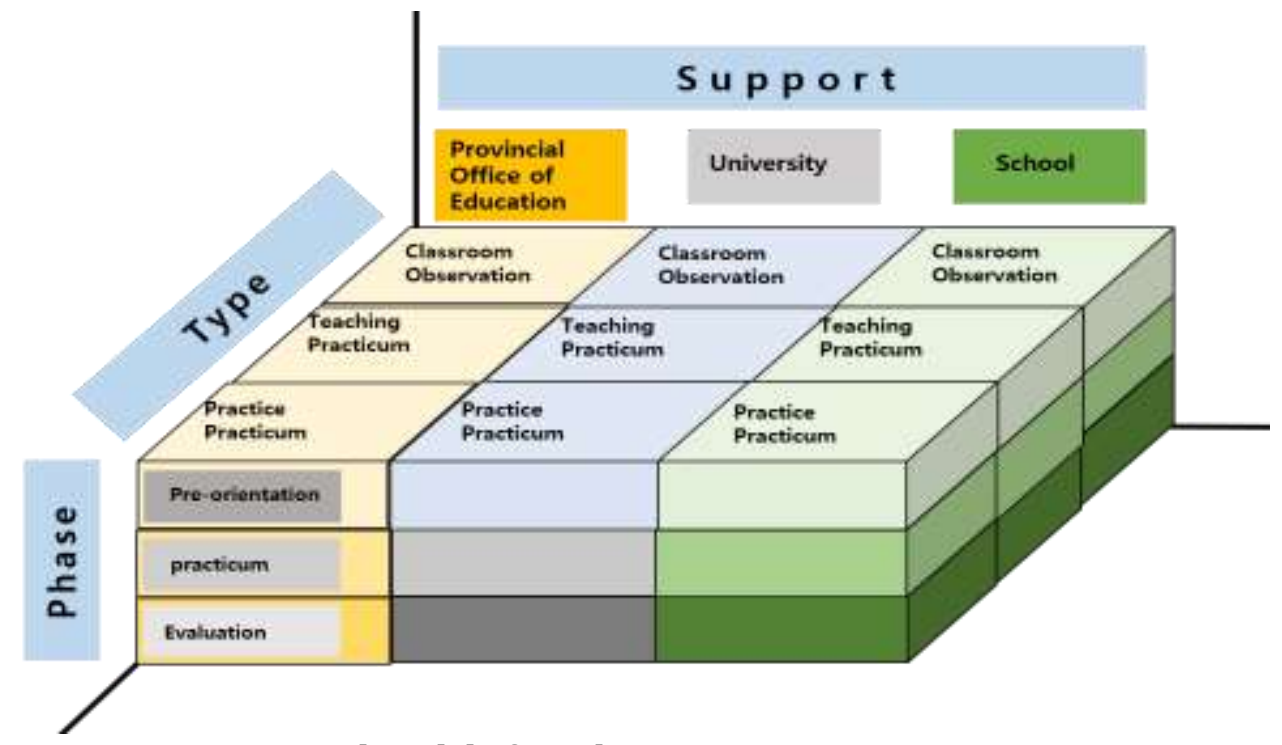

Figure3. 3D conceptual Model of Teaching Practicum

In the above model, each cell of the model is linked to pre-orientation, practicum-in-actio $\mathrm{n}$, and subsequent evaluation, depending on the type of practicum, and also to the content a nd roles to be supported by the office of education, university, and school level for each cou rse. In each of the three dimensions of the practicum (pre-orientation, practicum-in-action, eval uation) presented in this model, three types of practicum ( classroom observation, teaching practicum, and practical practicum), and three operating and suppor $t$ systems (the office of education, university, school) are presented. When the contents of the corresponding cell are arranged, about 27 different kinds of content can be extracted.

\subsection{Verification of the model}

To verify the validity of the 3D teaching practium conceptual model designed in this study, the researchers conducted a survey of two groups of experts. The first group of experts consisted of 20 professors from primary and secondary teacher training institutions, while the second group of experts consisted of 13 professional teachers. If the opinions of Group 1 and Group 2 of experts were equally valid, the validity of the concept model of the training exercise developed in this study would be more reliable. Otherwise, it would be necessary to re-validate the validity of this model. The results of the opinion survey of the two expert groups are as follows. 
First of all, a survey of the opinions of Group 1 of experts found that the definitions of each dimension, and sub-elements were higher than the standard values (CVR> 0.42). Therefore, this model has been confirmed to be valid [3]. Next, the results of the opinion survey of Group 2 of experts also confirmed the validity of this model by analyzing the definitions of each dimension, and sub-elements that make up the teaching practicum were higher than the reference value(CVR $>0.62)$. The results of the opinion survey the two expert groups' are shown in Table 1.

Table1. 2Experts Group Opinion Analysis Result

\begin{tabular}{|c|c|c|c|c|c|c|c|c|}
\hline \multirow{2}{*}{ Dimension } & \multirow{2}{*}{$\begin{array}{l}\text { Sub } \\
\text {-Element }\end{array}$} & \multirow{2}{*}{ Definition } & \multicolumn{3}{|c|}{ Expert Group 1} & \multicolumn{3}{|c|}{ Expert Group 2} \\
\hline & & & Mean & SD & CVR & Mean & SD & CVR \\
\hline \multirow{3}{*}{$\begin{array}{l}\text { Phase } \\
\text { (1D) }\end{array}$} & $\begin{array}{l}\text { Pre } \\
\text { Orientation }\end{array}$ & $\begin{array}{l}\text { A process to educate student } \\
\text { teachers before the teaching } \\
\text { practicum is conducted }\end{array}$ & 4.75 & 0.55 & 0.90 & 5.00 & 0.00 & 1.00 \\
\hline & $\begin{array}{l}\text { Practicum-in- } \\
\text { Action }\end{array}$ & $\begin{array}{l}\text { A process in which student } \\
\text { teachers experience the } \\
\text { school site as the teaching } \\
\text { practicum begins }\end{array}$ & 4.75 & 0.64 & 0.80 & 5.00 & 0.00 & 1.00 \\
\hline & Evaluation & $\begin{array}{l}\text { The process of evaluating and } \\
\text { giving feedback on student } \\
\text { teachers' teaching practicum } \\
\text { activities after the practice is } \\
\text { over }\end{array}$ & 4.70 & 0.66 & 0.80 & 4.69 & 0.63 & 0.85 \\
\hline \multirow{3}{*}{$\begin{array}{l}\text { Type } \\
\text { (2D) }\end{array}$} & $\begin{array}{l}\text { Classroom } \\
\text { Observation }\end{array}$ & $\begin{array}{l}\text { Types of activities to observe } \\
\text { and participate in the } \\
\text { educational field at the } \\
\text { beginning of the teaching } \\
\text { practicum }\end{array}$ & 4.35 & 0.88 & 0.50 & 4.85 & 0.38 & 1.00 \\
\hline & $\begin{array}{l}\text { Teaching } \\
\text { practicum }\end{array}$ & $\begin{array}{l}\text { Types of real class activities } \\
\text { in the mid-term of teaching } \\
\text { practicum }\end{array}$ & 4.45 & 0.83 & 0.60 & 5.00 & 0.00 & 1.00 \\
\hline & $\begin{array}{l}\text { Practical } \\
\text { Practicum }\end{array}$ & $\begin{array}{l}\text { Types of activities to } \\
\text { experience all school practice } \\
\text { related to the teaching } \\
\text { profession at the last stage of } \\
\text { the teaching practicum }\end{array}$ & 4.30 & 0.86 & 0.50 & 5.00 & 0.00 & 1.00 \\
\hline \multirow{3}{*}{$\begin{array}{l}\text { Support } \\
\text { System } \\
\text { (3D) }\end{array}$} & University & $\begin{array}{l}\text { Teaching practicum planning } \\
\text { and operation, guidance } \\
\text { system }\end{array}$ & 4.45 & 0.83 & 0.60 & 4.69 & 0.48 & 1.00 \\
\hline & $\begin{array}{l}\text { The Office of } \\
\text { Education }\end{array}$ & $\begin{array}{l}\text { Cooperative consultation } \\
\text { system between universities } \\
\text { and training schools for the } \\
\text { operation of teaching } \\
\text { practicum }\end{array}$ & 4.20 & 0.95 & 0.50 & 4.38 & 0.87 & 0.85 \\
\hline & School & $\begin{array}{l}\text { Guidance and guidance } \\
\text { system to provide } \\
\text { opportunities for } \\
\text { teachers and } \\
\text { teaching skills }\end{array}$ & 4.50 & 0.76 & 0.70 & 4.92 & 0.28 & 1.00 \\
\hline
\end{tabular}

As shown above, as a result of the opinion survey of the two expert groups, the validity values (CVR) of the three dimensions, sub-elements, and definitions of the conceptual model-of-teaching practicum were analyzed as higher than the standard value in both groups. Therefore, the conceptual model-ofteaching practicum developed in this study was verified by experts.

\section{Conclusions}


In this study, a conceptual model of teaching practicum was developed to systematically understand the phenomenon of education practice and to make its operation more efficient. The conceptual modelof- teaching practicum is meaningful in that: First, it will help each person in charge of each support system (administrators, university professors, mentors) understand their roles better. Second, it will reveal the role of each teaching practicum system more clearly in its actual operation because it shows the relationship between each element of the exercise. Third, it can help facilitate communication for the coordination, or collaboration of roles between each support system. Fourth, it can contribute to enhancing the development of the teaching practicum and promote quality improvement. Fifth, it can help institutes plan the teaching practicum process more flexibly, and, on the contrary, it is also useful for integrating and working on immediate issues. Sixth, it is also easy to use as an operational model of the teaching practicum, an evaluation model, and an online system model. As a result, we will be able to clearly distinguish and understand the relevant factors within the concepts of the teaching practicum from a comprehensive perspective. Therefore, the conceptual model-of-teaching practicum created through a theoretical approach can be used as basic data for systematic understanding and efficient operation of the phenomenon of the teaching practicum.

\section{Acknowledgements}

This work was supported by the Ministry of Education of the Republic of Korea and the National Research Foundation of Korea (NRF-2020S1A5B8103732.)

\section{References}

[1]Back, Y. S. et al. (2005) A Study on the Effective Field-Based Practicum through the Development of Mentoring Model for the Early Childhood Special Education Teacher Education Program. Korean Journal of early childhood special education. 5(2), 48-87.

[2] Cho S. I. (1997) A Study on the Improvement of Teaching Practicum by the Collaboration System Model between University and Cooperative School. Ph.D. Dissertation. Chungnam National University, South Korea.

[3] Cho, W. J., and Choi, I. S. (2006) Developing a Portfolio Model for Student Teachers. Early Childhood Education Research. 26(4), 239-259.

[4] Choi H. J., I. S. Park., and Y. H. Sol. (2020) A Study on the Development of A Conceptual Model of Teaching Practicum and Its Validity. Korea Journal of Education Research. 58(2), 385-409.

[5] Choi H. J., I. S. Park., and Y. H. Sol. (2020) Exploring the status and improvement plan of the school field practicum of secondary teacher training institutes. Journal of Learner-Centered Curriculum and Instruction. 20(6), 69-90.

[6] Go, Y. M. (2010) Development of an e-mentoring model between an instructing professor and preservice teachers for supervising the early childhood student teaching. Early Childhood Education Research, 30(1), 449-474.

[7] Jho, D. H., and Kim, J. Y. (2013) A Survey on the Current Status of Teaching Practicum in Secondary Schools: Implications for the Teaching Practicum Policy. Education Research. 57, 151-173.

[8] Kim, H. J. (2013) Development and Application of Education Practicum Program Model Based on Reflective Thinking. Ph.D. Dissertation. Seoul National University. South Korea.

[9] Kim, S. H., J.R. Won., and E. J. An. (2016) Development of a Practicum Program Model for Preservice Child Care Teachers for Infants and Children with Disabilities. Special Education Research. 15(1), 5171.

[10] Kim, N. S. et al. (2010) A base study to develop a model for student teaching guidance teacher training program of the industry-academic cooperation kindergartens. Journal of Early Childhood Education \& Educare Welfare. 14(4), 199-217.

[11] Park, G.S. (2008) Peer Coaching Model for Preservice Special Education Teachers Practicum. Journal of Special Education \& Rehabitation Science. 47(2), 1-19.

[12] Sol, Y. H., H. W. Park, and I. S. Park. (2019) An Analysis on the Operation of the Teaching Practicum at Teacher Preparation Institutions for Elementary Pre-service Teachers in Korea. The Journal of Korea Teacher Education. 36(1), 51-77.

[13]The Center for Global Teacher Education (2019), 2017 Selected Core Research Institute Phase 1, 2nd Year Report. The Center for Global Teacher Education, Gongju National University of Education, The National Research Foundation of Korea under Grant NRF-2017S1A5B8059786. 
